\title{
Rumos da educação nacional e formação de geocientistas
}

Investimentos em educação e desenvolvimento tecnológico são essenciais para aprimorar os padrões de bem-estar social de um povo, quer pela garantia de suprimento de recursos naturais, planejamento de uso da terra ou prevenção para conviver com o risco, quer para formar cidadãos aptos a construir e manter a democracia. Isso implica o desafio de formar geólogos que saibam mobilizar seu conhecimento técnico específico para resolver problemas econômicos e tecnológicos e, de outro, tenham capacidade e sensibilidade para pesar aspectos culturais e afetivos que ligam o povo ao local onde vive.

Houve, nos últimos anos, expansão dos cursos de Geologia, apoiada em políticas bem-sucedidas de fortalecimento do ensino público superior que não estão porém isentas de críticas e reparos, sobretudo diante das agudas carências de recursos materiais e financeiros. São cursos duplamente penalizados: dependem de altos investimentos em atividades práticas de laboratório e campo, e precisam atrair professores muito disputados por organismos públicos e privados, especialmente no caso de profissionais mais experientes.

É difícil questionar o aparato, apoiado em fundos sociais, que reivindica melhorar os níveis educacionais e expandir o vínculo escolar dos jovens. Garantem-se benefícios legais às famílias que mantiverem filhos na escola. A educação bási$\mathrm{ca}$, apoiada em recursos pulverizados nos estados e municípios, tornou-se obrigatória. Neste País, um jovem de 16 anos pode votar, em outros países pode guiar carros, mas foi proibido de dizer: não quero estudar. A lei obriga o governo a manter um enorme programa de livro didático, que adquire dezenas de milhões de exemplares anuais. A lei obriga o governo a garantir transporte dos alunos para escolas. Mas a lei nada diz sobre condições dignas de vida e aperfeiçoamento de professores.

Os professores são responsáveis por conduzir um ensino que garanta a aprendizagem. Identificar problemas do currículo escolar deveria ser a prioridade dos exames de avaliação do ensino médio, mas as provas deixaram em segundo plano esse papel, e passaram a constituir critério de ingresso no ensino superior, em lugar do vestibular. Do cuidado exacerbado com a avaliação emergem indicadores objetivos dos melhores e piores colégios; algumas escolas privadas montam curiosa estratégia de marketing: fazem ofertas atraentes aos melhores alunos, para depois divulgar suas boas notas. Educação e saber transformam-se, uma vez mais, em serviço e mercadoria. Subverte-se o rigor que conduz à aprendizagem de conteúdos e atitudes pelo critério técnico para medir e avaliar o rendimento individual com precisão "cirúrgica". São escolhas repletas de contradições, até mesmo porque a qualidade do ensino pouco melhorou.

Professores de ensino médio precisam sempre atualizar-se em atividades práticas e formular novas idéias para aulas. Este número de Terræ Didatica continua a publicar experiências práticas testáveis e replicáveis. O artigo de abertura, em formato bilíngue, foi adotado na oficina didática GIFT (Geophysical Information for Teachers), realizada pela American Geophysical Union, durante o "2010 The Meeting of the Americas", em Foz do Iguaçu, agosto de 2010. O texto aborda o uso prático de dados de satélite TRMM (Tropical Rainfall Measuring Mission). No curso, apresentaramse resultados de pesquisas relacionadas a chuva, rochas e solos, com ênfase em sensoriamento remoto.

Em 2010 Terræ Didatica inicia nova etapa: dois números comporão o volume 6 , atingindo-se periodicidade semestral. O material em avaliação ou já aprovado é suficiente para finalizá-lo. Fazemos, pois, chamada de trabalhos (call for papers) para o volume de 2011.

Os demais trabalhos incluídos neste número iluminam aspectos variados das Ciências da Terra; procuramos, assim, apoiar o esforço de educadores e estudantes em sua constante busca por novos conhecimentos e saberes.

Os Editores Campinas, agosto de 2010. 